Keywords: Forest community functional diversity functional traits community structure environmental gradient

Histórico: Recebido 12/1 1/2016 Aceito 30/01/2017

Palavras chave: Comunidade florestal Diversidade funcional Características funcionais Estrutura da comunidade Gradiente ambiental

Correspondência: zhangjt@sxu.edu.cn

\section{FUNCTIONAL DIVERSITY AND ITS ATTRIBUTE FACTORS IN THE YUNMENG MOUNTAIN NATIONAL FOREST PARK IN BEIJING, CHINA}

ABSTRACT: The interaction of diversity with environmental gradients is an important topic in ecology. This study investigated the pattern of change in functional diversity in forest communities along an altitudinal gradient in Yunmeng Mountain National Forest Park, China. Forty-two quadrats measuring $10 \times 10 \mathrm{~m}$ in the forest communities were set up along this altitudinal gradient; plant species, traits and environmental variables were measured and recorded. Six functional diversity indices, namely, Modified functional attribute diversity (MFAD), Functional diversity plot-based dendrogram index (FDp), Functional diversity community-based dendrogram index (FDc), Functional evenness (FEve), Functional divergence (FDiv) and Functional dispersion (FDis), were used to calculate functional diversity. The results showed that functional diversity varied greatly in forest communities in the Yunmeng Mountain Forest Park. Functional diversity was significantly correlated with elevation and slope position and somewhat correlated with soil depth. Functional diversity increased with an increase in the elevation and decreased as the slope position changed from valley bottom to hill ridge. Functional diversity was closely related to species richness. The six functional diversity indices were all applicable to functional diversity studies of forest communities.

\section{DIVERSIDADE FUNCIONAL E SEUS FATORES DE ATRIBUTO NO PARQUE FLORESTAL NACIONAL DA MONTANHA YUNMENG EM PEQUIM, CHINA}

RESUMO: A interação da diversidade com gradientes ambientais é um tópico importante na ecologia. Este estudo investigou o padrão de mudança na diversidade funcional em comunidades florestais ao longo de um gradiente altitudinal no Parque Florestal Nacional da Montanha Yunmeng, China. Quarenta e dois quadrantes medindo $10 \times 10 \mathrm{~m}$ foram alocados nas comunidades florestais ao longo deste gradiente altitudinal; espécies $\mathrm{e}$ características de plantas, bem como variáveis ambientais foram medidas e registradas. Seis índices de diversidade funcional, sendo eles, atributo funcional de diversidade modificado (MFAD), índice de diversidade funcional baseada no dendrograma da parcela (PDp), índice de diversidade funcional baseada no dendrograma da comunidade (FDc), regularidade funcional (FEve), divergência funcional (FDiv) e dispersão funcional (FDis), foram utilizados para calcular a diversidade funcional. Os resultados mostraram que a diversidade funcional variou muito nas comunidades florestais do Parque Florestal da Montanha Yunmeng. Diversidade funcional foi significativamente correlacionada com a elevação e a posição de inclinação do terreno e pouco correlacionada com profundidade de solo. Diversidade funcional aumentou com o aumento na elevação e diminuiu quando a posição de inclinação mudou de fundo de vale para o cume da colina. Diversidade funcional foi altamente relacionada com riqueza de espécies. Os seis índices de diversidade funcional são aplicáveis a estudos de diversidade funcional de comunidades florestais. 


\section{INTRODUCTION}

Functional diversity can reflect ecosystem functions and their changes (PODANI and SCHMERA, 2006), and it is related to community composition, structure, and interactions with environmental gradients (PETCHEY and GASTON 2002; SPASOJEVIC et al. 2014; ZHANG et al. 20I5a). Therefore, functional diversity has become a key concept in studies of biodiversity and ecosystem functioning (ACKERLY and CORNWELL, 2007; CASANOVES et al., 20II). Functional diversity is the variation of species functions within a community or ecosystem, and functional traits can be used to reflect species functions in a community (Mason et al. 2005). Some authors have used the term "functional trait diversity" to denote functional diversity (ZHANG et al., 20I3a). The different types of and changes in plant functional traits can be used to describe the amount of community functional diversity (VILLEGER et al., 2008).

Studies on functional diversity are the bases for nature conservation and have been paid much attention by conservationists and ecologists (AUSTRHEIM, 2002; MUHUMUZA and BYARUGABA, 2009). In a large city such as Beijing, mountains are extremely important in nature conservation and ecological protection for citizens because most natural forests occur in mountainous regions of limited area (LOMOLINO, 200I; CUI et al., 2008). Patterns of variation of species diversity along environmental gradients in mountains have frequently been studied (AUSTRHEIM, 2002; PAVOINE and BONSALL, 20II; PERRONNE et al., 20I4). However, functional diversity and its patterns of change along environmental gradients have not yet been adequately analyzed (FETENE et al., 2006; ALBERT et al., 20I2; ZHANG et al., 20I4).

The Yunmeng Mountain National Forest Park is the closest forest park to downtown Beijing city and is a well-known eco-tourism site for citizens (ZHANG et al., 20I3b; SPASOJEVIC et al., 20I4). Secondary forests are significant for economic and ecological development in this region and should be under reasonable conservation and utilization. Some studies related to ecology, including floristic characteristics and plant species resources (HE et al., 1992), tourism resources and assessment (WANG et al. 2004), restoration and recovery of degraded vegetation at lower areas (DAl et al., 1990), have been conducted in the Yunmeng Mountain Forest Park. However, the changes in functional diversity associated with the major environmental gradients have not been examined in this forest park. In this work, we attempt to characterize the pattern of functional diversity variation of secondary forest communities along environmental gradients, to identify the key environmental variables affecting functional diversity, to test the hypothesis that the highest functional diversity may appear at middle elevations along elevation gradients in the Yunmeng Mountain Forest Park, and to test the effectiveness and applicability of functional diversity indices.

\section{MATERIALS AND METHODS}

\section{Study area}

The Yunmeng Mountain National Forest Park (YMNFP), located at 40 $26^{\prime}-40^{\circ} 38^{\prime} \mathrm{N}, 116^{\circ} 40^{\prime}-$ $116^{\circ} 50^{\prime} \mathrm{E}$, is in the Huairou district and Miyun county of the Beijing city administrative entity and is approximately $85 \mathrm{~km}$ from downtown Beijing. YMNFP has an area of 2208 ha. Its elevation varies from $700 \mathrm{~m}$ to $1,414 \mathrm{~m}$. The climate of this region is typical warm-temperate and is strongly affected by the subhumid monsoon from the southeast. The annual mean temperature is approximately $10^{\circ} \mathrm{C}$, and the mean monthly temperatures in January and July are $-7^{\circ} \mathrm{C}$ and $25^{\circ} \mathrm{C}$, respectively. The annual mean precipitation varies between $600 \mathrm{~mm}$ and $700 \mathrm{~mm}$. During the year, most precipitation (more than $70 \%$ ) falls from June through September. The main soil types are drab soil and brown forest soil. The vegetation is mainly secondary broad-leaved deciduous forest, with a small area of planted coniferous forest. YMNFP is a significant eco-tourism destination for Beijing's citizens. It has beautifully strange peaks, exquisitely grotesque rocks, ponds and waterfalls, forests, and striking and vividly memorable landscapes (WANG et al. 2004).

\section{Sampling}

Based on a general survey, 15 sampling plots separated by 50 meters in altitude were set up along an elevational gradient between 750 and I4I4 m ASL. We established 2-4 quadrats of $10 \mathrm{~m} \times 10 \mathrm{~m}$ within each sampling plot along the contour line. In all, there were 42 quadrats. The species name, abundance, cover, height and basal area for tree species ( $\mathrm{DBH}>2.5 \mathrm{~cm}$, height $>3 \mathrm{~m}$ ), and the species name, cover and average height for shrub and herb species were measured and recorded in each quadrat. The tree height was measured with a laser height meter (RD 1000), and shrub and herb height were measured with a steel tape measure.

Twelve functional traits were chosen to demonstrate species functions in the plant community (Table I). The pollination mechanism, photosynthetic pathway, seed dispersal, root system, and nitrogen-fixing type were identified from local floras. Leaf form, life-form, plant height, flowering date and period, fruit mature date, 
TABLE I Plant functional traits and their values in forest communities in the Yunmeng Mountain Forest Park, China.

\begin{tabular}{|c|c|c|}
\hline Functional trait type & Data type & Functional traits and values \\
\hline Photosynthesis pathway & Categorical value & I Crassulacean pathway, 2 C3 pathway, 3 between $C 3$ and C4 pathway, 4 C4 pathway \\
\hline Nitrogen-fixing & Categorical value & 0 No nitrogen-fixing, I Elaeagnaceae nitrogen-fixing, 2 Leguminosae nitrogen-fixing \\
\hline Seed dispersal & Categorical value & I Automatic spreading, 2 gravity spreading, 3 wind spreading, 4 animals spreading, 5 non-flowering plant \\
\hline Pollination method & Categorical value & I Anemophilous, 2 entomophilous, 3 self-pollinated \\
\hline Life cycle & Categorical value & I Annual, 2 biennial, 3 perennial \\
\hline Life-form & Categorical value & I Tree, 2 shrubs, 3 woody vine, 4 perennial herb, 5 annual herb \\
\hline Leaf form & Categorical value & I Coniferous, 2 broad leaf, 3 non leaf \\
\hline Root system & Categorical value & I taproot system, 2 fiber system \\
\hline Plant height & Quantitative value & Measured value in $\mathrm{m}$ \\
\hline Flowering date & Quantitative value & Initial month of flowering \\
\hline Flowering period & Quantitative value & Flowering months \\
\hline Fruit mature date & Quantitative value & Initial month of fruit maturation \\
\hline
\end{tabular}

and life cycle were investigated in the field. To calculate functional diversity indices, a data matrix of plant species by functional traits in a quadrat was constructed, with a total of 42 data matrices for the 42 quadrats.

Six environmental factors, namely, altitude, slope, slope aspect, slope position, litter thickness, and soil depth were also measured and recorded for each quadrat. A GPS was used to measure elevation, and a compass meter was used to measure the slope and slope aspect. The soil depth was measured with a soil depth instrument, and the litter thickness was measured directly with a ruler. The measured values of slope aspect were transformed into values on a numerical scale of I through 8 as follows: I (337.6 ${ }^{\circ}$ $\left.360^{\circ}, 0-22.5^{\circ}\right), 2\left(22.6^{\circ}-67.5^{\circ}\right), 3\left(292.6^{\circ}-337.5^{\circ}\right), 4$ $\left(67.6^{\circ}-112.5^{\circ}\right), 5\left(247.6^{\circ}-292.5^{\circ}\right), 6$ (I $\left.52.6^{\circ}-157.5^{\circ}\right)$, $7\left(202.6^{\circ}-247.5^{\circ}\right)$, and $8\left(157.6^{\circ}-202.5^{\circ}\right)$. The greater the value is, the more sunlight availability is. The slope position was recorded on a scale of I - 5 for valley bottom; lower, middle, and upper hill positions; and hill ridge, respectively (ZHANG et al., 2014).

\section{Functional diversity indices}

Six common indices for measuring functional diversity were used to calculate functional diversity in the studied communities:

\section{Modified functional attribute diversity (MFAD)}

For a data matrix of $S$ species $\times N$ traits, the functional units were defined by combining the species with the same values on all of the traits into one unit. This procedure will reduce the number of distinct species categories considered from $S$ to $M(M \leq S)$, where $d_{i j}$ is the distance between functional units $i$ and $j$ and $M$ is the number of functional units.

$M F A D=\frac{\sum_{i, j}^{M} d_{i j}}{M}$
Functional diversity based on dendrogram (FDp and FDc)

Functional diversity based on a dendrogram refers to the sum of the branch lengths of the dendrogram produced by a clustering based on a data matrix of species $\times$ traits. FDp denotes the plot-based functional diversity index, and FDc denotes the community-based index (PETCHEY and GASTON 2006).

\section{Functional evenness (FEve)}

FEve measures the regularity of spacing between species in the functional trait space and the evenness in the distribution of species abundance. The minimum spanning tree (MST) was used to transform a multidimensional space to a distribution on a single axis. This index measures both the sum of branch lengths in the MST and the evenness in species abundances (VILLÉGER et al. 2008). This index is defined as follows:

$$
\begin{aligned}
& F E v e=\frac{\sum_{b=1}^{S-1} \min \left(P E W_{b}, \frac{1}{S-1}\right)-\frac{1}{S-1}}{1-\frac{1}{S-1}} \\
& P E W_{b}=\frac{E W_{b}}{\sum_{b=1}^{S-1} E W_{b}} \\
& E W_{b}=\frac{d_{i j}}{w_{i}+w_{j}}
\end{aligned}
$$

There are $S$-I branches in an MST containing $S$ species, and each of the $b$ branch lengths is divided by the sum of the abundance of the species linked. $E W_{b}$ is the weighted evenness, $d_{i j}$ is the Euclidean distance between species $i$ and $j$ on branch $b$, and $w_{i}$ and $w_{j}$ are the relative abundances of these species. It is useful to compute the partial weighted evenness by dividing by the sum of the weighted evenness values across the branches.

Functional divergence (Fdiv)

Functional divergence is related to the way in which abundance is distributed within the volume of the 
functional trait space, where $d G_{i}$ is the functional distance from species $i$ to the center of gravity of the species that form the vertices of the convex hull; and $\overline{d G}$ is the mean distance of the $S$ species to the center of gravity; and $w_{i}$ is the relative abundance of species $i$.

$F D i v=\frac{\sum_{i=1}^{S} w_{i}\left(d G_{i}-\overline{d G}\right)+\overline{d G}}{\sum_{i=1}^{S} w_{i}\left|d G_{i}-\overline{d G}\right|+\overline{d G}}$

\section{Functional dispersion (Fdis)}

Fdis is the mean distance of the species to the centroid I of all species in the functional trait space. This index considers the relative abundance. $C=\left\{c_{1}, c_{2}, \ldots, c_{N}\right\}$ is the vector having the coordinates of the weighted centroid in the $\mathrm{N}$-dimensional trait space, and $\mathrm{N}$ is the number of traits, where $w_{i}$ is the relative abundance of species $i$ and $z_{i}$ is the distance of species $\mathrm{i}$ to the weighted centroid C.

FDis $=\sum_{i=1}^{S} w_{i} z_{i}$

\section{Species diversity}

The following four species diversity indices were used; species number (as a richness index), $D=S$; the Shannon-Wiener index: $H^{\prime}=-\sum P_{i} \ln P_{i}$; the Simpson index: $D=1-\sum_{i=1}^{S}\left(P_{i}\right)^{2}$ and the Pielou evenness index, $E=H^{\prime} / \ln (S)$. In these formulas, $P_{i}$ is the relative abundance of species $i$, $P_{i}=N_{i} / N, N_{i}$ is the abundance of species $i, N$ is the sum of abundance for all species in a quadrat, and $S$ is the number of species present in a quadrat.

Spearman correlation and regression analyses were used to analyze the relationships among functional diversity, environmental variables and species diversity.

\section{RESULTS}

The functional diversity demonstrated by the six indices showed marked changes in the forest communities in the Yunmeng Mountain Forest Park. Modified functional attribute diversity (MFAD)varied between I.93I and 4.265, Functional diversity plot-based dendrogram index (FDp) between 3.609 and 7.248, Functional diversity community-based dendrogram index (FDc) between 3.520 and 6.599, Functional evenness (FEve) between 0.331 and 0.652 , Functional divergence (FDiv) between 0.400 and 0.958, and Functional dispersion (FDis) between 1.943 and 5.6I4.

Functional diversity was significantly correlated with elevation (Figure I) and with slope position (Fig. 2) in the Yunmeng Mountain Forest Park. All six indices showed similar relationships with elevation and slope position gradients. Functional diversity increased with elevation and reached its maximum near the summit of the mountain (Figure I). Functional diversity gradually decreased with slope position, changing from the valley bottom to the hill ridge, with the maximum values at the valley bottom and lower hill positions (Figure 2). The relationships between functional diversity and elevation and slope position were non-linear. The six functional diversity indices provided similar results because they were closely related to each other (Table 2).

TABLE 2 Spearman correlation coefficients between functional diversity indices in the Yunmeng Mountain Forest Park, China.

\begin{tabular}{ccccccc}
\hline & MFAD & FDp & FDc & FEve & FDiv & FDis \\
\hline MFAD & 1.000 & & & & & \\
FDp & $0.526 * * *$ & 1.000 & & & & \\
FDc & $0.579 * * *$ & $0.656 * * *$ & 1.000 & & & \\
FEve & $0.332 *$ & 0.263 & $0.321^{*}$ & 1.000 & & \\
FDiv & $0.530 * * *$ & $0.550 * * *$ & $0.522^{* * *}$ & 0.268 & 1.000 & \\
FDis & $0.394 * *$ & $0.598 * * *$ & $0.701 * * *$ & 0.067 & $0.386 *$ & 1.000 \\
\hline
\end{tabular}

* $\mathrm{P}<0.05, * * \mathrm{P}<0.01,{ }^{*} * * \mathrm{P}<0.001$

In addition to elevation and slope position, soil depth was also important in influencing spatial variation of functional diversity in the Yunmeng Mountain Forest Park (Table 3). The litter thickness played a special role in functional evenness (FEve). However, the slope and aspect were not significant for functional diversity change in the Park (Table 3). Although different indices showed different significances for their relationships with functional diversity, the positive or negative nature of the relationships was clear. Elevation, soil depth and litter thickness had positive correlations, slope position and aspect negative correlations with the functional indices (Table 3).

TABLE 3 Spearman correlation coefficients between functional diversity and environmental variables in the Yunmeng Mountain Forest Park, China.

\begin{tabular}{|c|c|c|c|c|c|c|}
\hline & Elevation & Aspect & Slope & $\begin{array}{c}\text { Slope } \\
\text { position }\end{array}$ & Soil depth & $\begin{array}{c}\text { Litter } \\
\text { thickness }\end{array}$ \\
\hline MFAD & $0.516^{* * * *}$ & 0.102 & 0.219 & $-0.48 \mid$ I*** & $0.424 * *$ & 0.065 \\
\hline FDp & $0.628 * * *$ & -0.012 & 0.091 & $-0.594 * * *$ & $0.424 * *$ & 0.109 \\
\hline FDc & $0.609 * * *$ & -0.114 & 0.034 & $-0.569 * * * *$ & $0.627^{* * * *}$ & 0.219 \\
\hline FEve & $0.5 \mid 4^{* * * *}$ & -0.130 & 0.137 & $-0.400 * *$ & 0.299 & $0.313^{*}$ \\
\hline FDiv & $0.580 * * * *$ & -0.116 & 0.139 & $-0.580 * * * *$ & $0.5 \mathrm{II}$ 米** & 0.173 \\
\hline FDis & $0.386 *$ & 0.047 & 0.053 & $-0.405^{* *}$ & $0.550 * * * *$ & 0.071 \\
\hline
\end{tabular}

* $\mathrm{P}<0.05, * * \mathrm{P}<0.01, * * * \mathrm{P}<0.001$ 

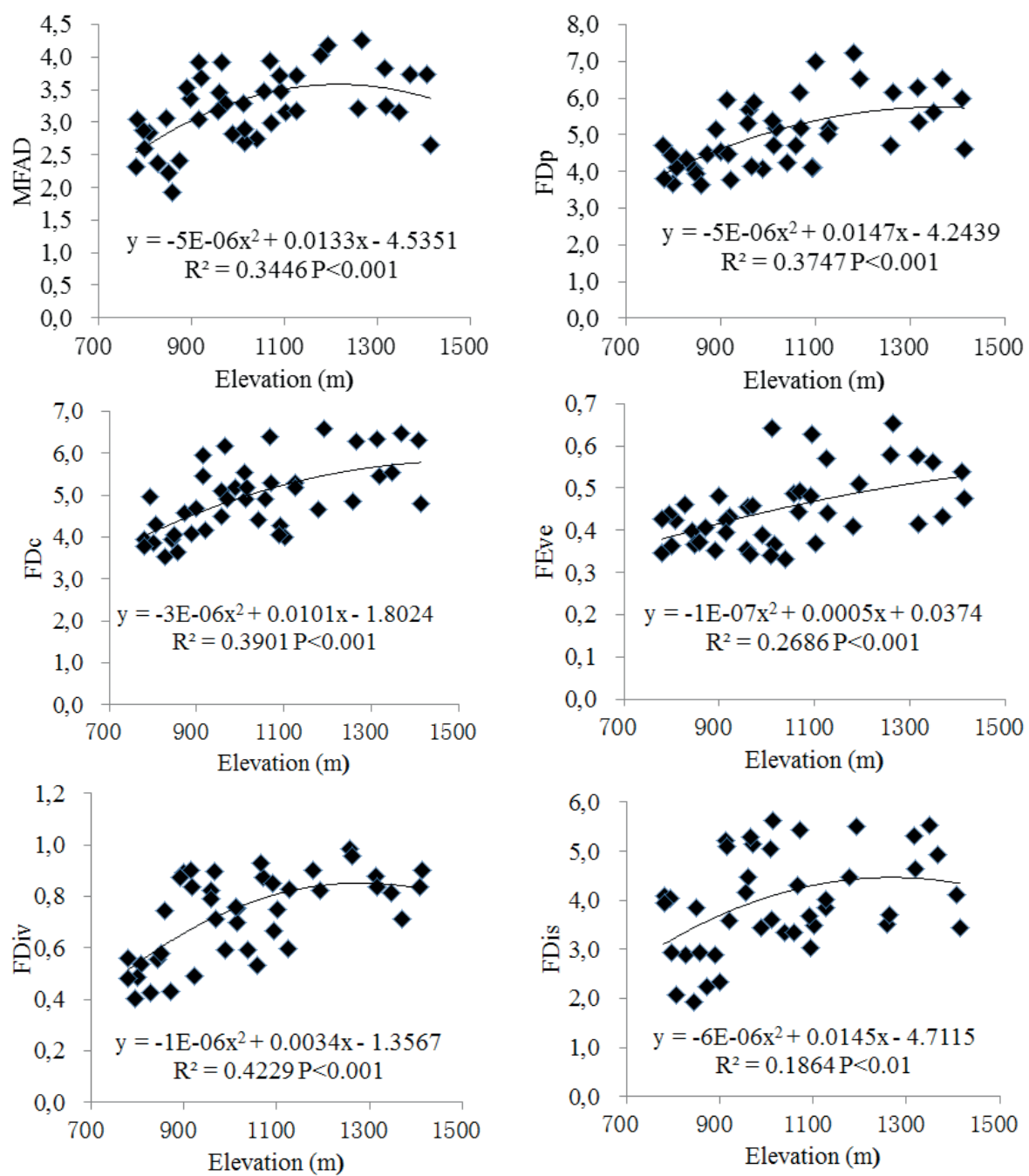

FIGURE I Change of functional diversity along an elevational gradient in the Yunmeng Mountain Forest Park, China. MFAD, FDp, FDc, FEve, FDiv, and FDis refer to modified functional attribute diversity, plot-based functional diversity, communitybased functional diversity, functional evenness, functional divergence, and functional dispersion indices, respectively.

All of the functional diversity indices were significantly correlated with species richness and diversity (Shannon-Wiener index) in the studied forest communities (Figure 3, Table 4). Functional diversity was positively related to species richness and diversity, i.e., functional diversity increased with species richness and diversity increased. The relationships of functional diversity to species evenness and the Simpson index were not significant.

\section{DISCUSSION}

Functional diversity is an indicator of ecosystem functioning (MASON et al., 2005) and can be used to demonstrate the relationships among community composition, structure, function and environmental variables (ZHANG et al., 20I3a). The studied functional diversity indices changed markedly in the forest communities of the Yunmeng Mountain Forest Park. This result suggested that forest communities differ in species composition, diversity, structure, function and

TABLE 4 Spearman correlation coefficients between functional diversity and species diversity in the Yunmeng Mountain Forest Park, China.

\begin{tabular}{ccccc}
\hline & $\begin{array}{c}\text { Species } \\
\text { richness }\end{array}$ & $\begin{array}{c}\text { Shannon-Wiener } \\
\text { index }\end{array}$ & $\begin{array}{c}\text { Pielou } \\
\text { Evenness }\end{array}$ & $\begin{array}{c}\text { Simpson } \\
\text { index }\end{array}$ \\
\hline MFAD & $0.611^{* * * *}$ & 0.247 & -0.201 & 0.162 \\
FDp & $0.425^{* *}$ & $0.340 *$ & -0.016 & 0.026 \\
FDc & $0.391^{*}$ & $0.396^{* *}$ & 0.019 & -0.083 \\
FEve & 0.046 & 0.036 & -0.167 & 0.186 \\
FDiv & $0.404 * *$ & 0.203 & -0.147 & 0.271 \\
FDis & 0.281 & $0.428^{* *}$ & 0.133 & -0.300 \\
\hline
\end{tabular}

* $P<0.05$, ** $P<0.01$, *** $P<0.001$ 

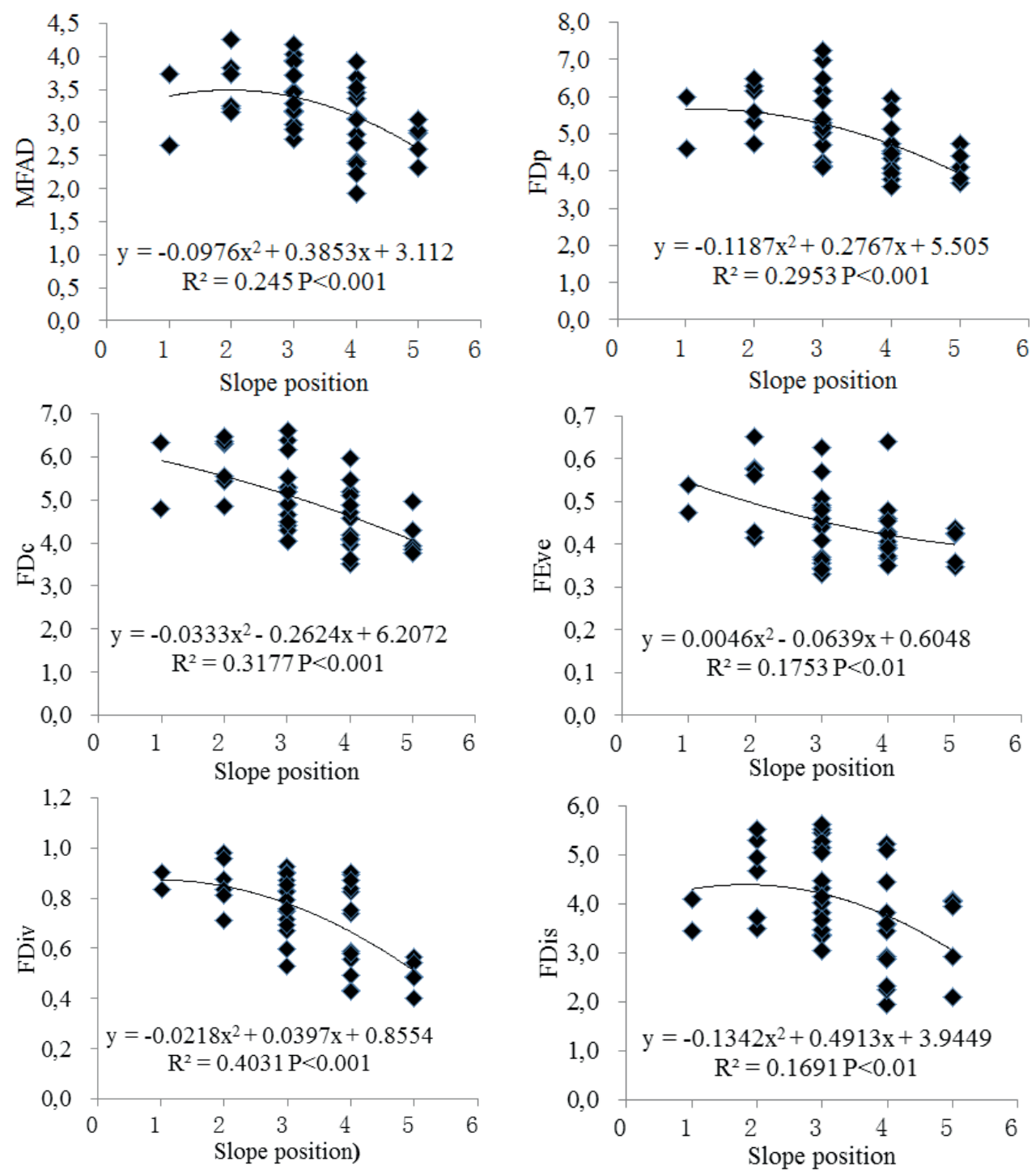

FIGURE 2 Relationships of functional diversity with slope position in the Yunmeng Mountain Forest Park, China. MFAD, FDp, FDc, FEve, FDiv, and FDis refer to modified functional attribute diversity, plot-based functional diversity, communitybased functional diversity, functional evenness, functional divergence, and functional dispersion indices, respectively.

environment (DE BELLO et al., 2006). There were eight forest communities distributed along the altitudinal gradient in the Yunmeng Mountain Forest Park (DAl et al., 1990). They were, from the lower to the upper hills, Comm. Pinus tabulaeformis, Comm. Juglans mandshurica, Comm. Fraxinus rhynchophylla + Acer truncatum + Tilia amurensis, Comm. Quercus mongolica, Comm. Betula dahurica, Comm. Populus davidiana + Betula platyphylla, and Comm. Larix principis-rupprechtii (CUI et al., 2008; ZHANG et al., 20l3b). The variation in functional diversity along the studied elevational gradient is consistent with that of the forest communities. Each community has its own composition, structure, function and inner environment and therefore has special functional diversity (SPASOJEVIC et al. 20I4; ZHANG et al. 2014).
Functional diversity indices were significantly correlated with elevation and slope position gradients in the Park. This result suggests that elevation and slope position were key factors affecting functional diversity in this park (DE BELLO et al. 2006; ZHANG et al. 2014). This finding was consistent with the conclusion that elevation and slope position were the most important environmental variables influencing forest structure, diversity and distribution in the studied park (DAl et al. 1990; CUl et al. 2008). All six indices showed the same pattern, namely, that forest functional diversity increased in a polynomial manner along the elevational gradient (ZHANG et al. 20I3a). This is due to that different elevation represents different environmental conditions. The maximum functional diversity appeared near the summit of the mountain 

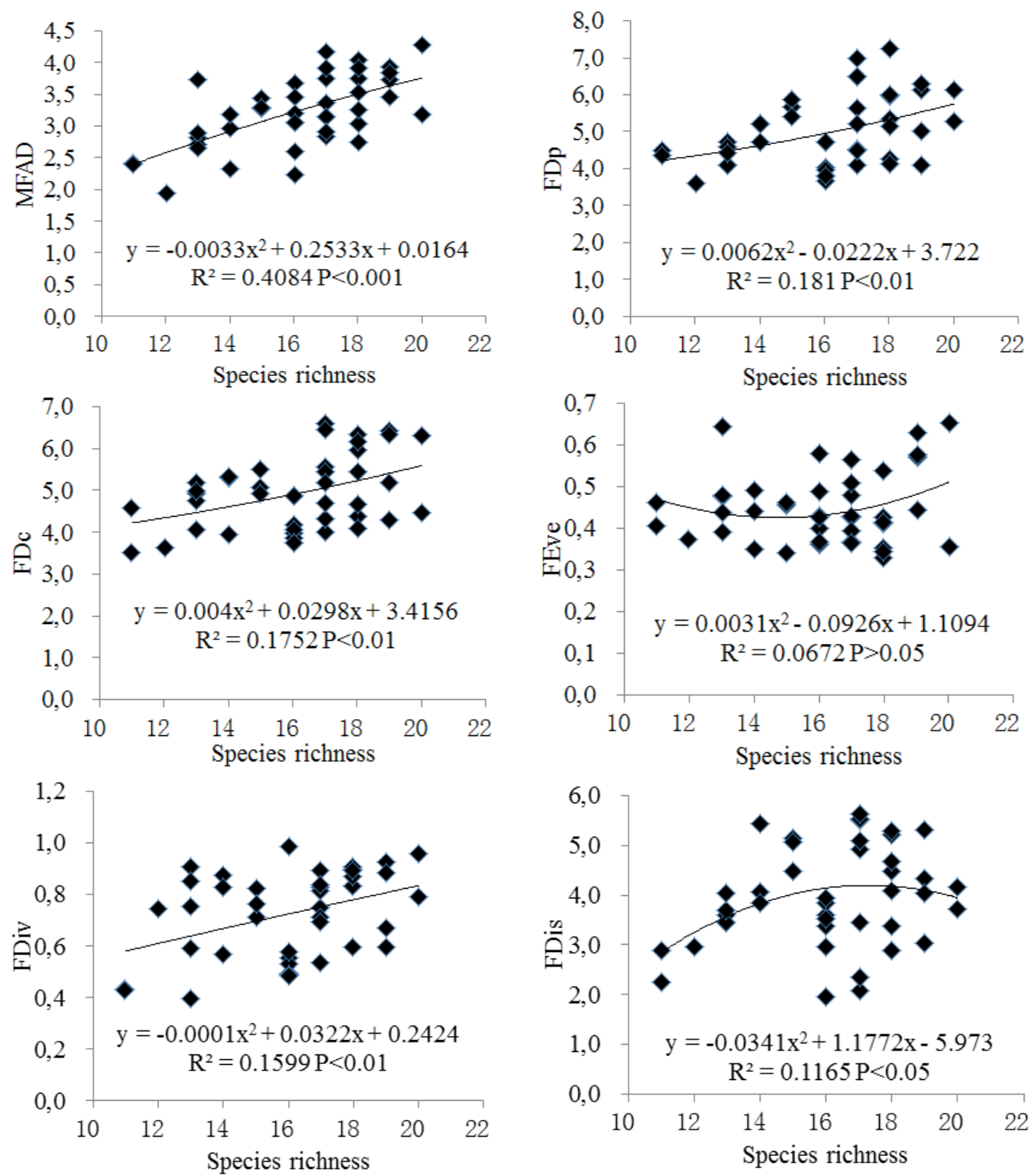

FIGURE 3 Relationships of functional diversity to species richness in the Yunmeng Mountain Forest Park, China. MFAD, FDp, FDc, FEve, FDiv, and FDis refer to modified functional attribute diversity, plot-based functional diversity, community-based functional diversity, functional evenness, functional divergence, and functional dispersion indices, respectively.

( $1414 \mathrm{~m})$, the minimum functional diversity at the base of the mountain $(750 \mathrm{~m})$. Usually, an elevation gradient represents a comprehensive gradient of temperature and water conditions in temperate mountains, i.e., changes in temperature and water conditions will affect the pattern of change of functional diversity with elevation (AUSTRHEIM, 2002; PERRONNE, et al. 20I4). The pattern, found by this study, of change in functional diversity along the elevation gradient is not consistent with the most commonly observed pattern, namely, that the highest diversity appears at intermediate elevations (ZHANG, et al. 2013c; VILLEGER, et al. 2008). The reason for this difference is that the elevational gradient from $750 \mathrm{~m}$ to $\mathrm{I}, 414 \mathrm{~m}$ is relatively short in the Yunmeng
Mountain Forest Park (BOEHNKE, et al. 20I4). Some other studies on low or middle mountains gave the similar results (PERRONNE, et al. 20I4; ZHANG, et al. 2014; TARDELLA, et al. 2016 ).

All of the indices showed the same pattern, namely, that forest functional diversity decreased in a polynomial manner along the slope position gradient from the valley bottom to the hill ridge in the Park (ZHANG, et al. 20I3b). Along this gradient, the water conditions, soil depth, and litter thickness decreased, while temperature and light availability increased, further influencing functional diversity (SPASOJEVIC, et al. 20I4).

Soil depth also significantly affected functional diversity in the Yunmeng Mountain Forest Park. This result is 
consistent with the general conclusion that soil depth and soil type are significant for forest distribution and development in the Beijing Mountains (ZHANG et al., 20I4). Soil depth is related to root system volume and nutrient availability (PERRONNE et al., 20I4), and hence, influences functional diversity (BOEHNKE et al., 20I4). Functional evenness was correlated with litter thickness. This result may reflect soil water and nutrient properties, patterns, and characteristics (DUIVENVOORDEN and CUELLO, 20I2).

Functional diversity was closely related to species richness and diversity in the Park. All of the functional diversity indices increased in a polynomial manner as species richness and diversity increased, i.e., these relationships were nonlinear (RICOTTA and MORETTI 2008; ZHANG et al. 20I3c). This finding suggested that functional diversity and species richness and diversity were interrelated with each other but were distinct and not mutually interchangeable (BUTTERFIELD and SUDING 20I3; ZHANG et al. 20I4). Some changes in functional traits may go beyond the sorts of variations that can be interpreted only based on taxonomic variation (DE BELLO et al. 2009; CASANOVES et al. 20I I), and this entire question merits further study. Our study has shown that functional diversity and species diversity can be used as indicators of forest composition, structure, functioning, and inner environment and should not be interchanged (ZHANG et al. 20I4).

The six functional diversity indices used were all effective in quantifying functional diversity and its variation in the forests of the Yunmeng Mountain Forest Park. These indices were all based on the functional distances between species in functional trait space; they reflect certain theoretical differences (SONG and ZHANG 20I3; CASANOVES et al. 20II). MFAD combined species with the same trait values into a functional unit; FDp and FDc were based on the sum of the lengths of the dendrogram branches; FEve emphasized the evenness of species traits and abundance; FDiv was related to the abundance distribution within the functional volume; and FDis measured the distance of species from the functional centroid (CASANOVES et al. 20 I I; BOEHNKE et al. 20l4; ZHANG et al. 20I5b). The similar results found for these indices in the current study's analysis of functional diversity reflected that they were correlated with each other; as also argued elsewhere, it is preferable to use only a few selected indices in the same study (AUSTRHEIM 2002; ZHANG et al. 20I3c). MFAD, FDc and FDiv should be recommended in the similar studies according to the results of this work.

\section{ACKNOWLEDGMENTS}

We thank the three anonymous referees and editors for their constructive comments and suggestions on the manuscript. This study was financially supported by the National Natural Science Foundation of China (No. 31170494) and the Specialized Research Fund for the Doctoral Program of Higher Education (Grant No. 20120003 I I0024).

\section{REFERENCES}

ACKERLY, D. AND CORNWELL W. A. trait-based approach to community assembly: partitioning of species trait values into within-and among-community components. Ecology Letters I0(2): 135-145, 2007.

AlBert, C.H., DE BELLO, F., BOULANGEA,T, I., PELLET, G., LAVOREL, S., THUILLER, W. On the importance of intraspecific variability for the quantification of functional diversity. Oikos I2I: II6-126, 2012.

AUSTRHEIM, G. Plant diversity patterns in semi-natural grasslands along an elevational gradient in southern Norway. Plant Ecology I6I (2): 193-205, 2002.

BOEHNKE, M., KROEBER, W., WELK, E., WIRTH, C., BRUELHEIDE, H. Maintenance of constant functional diversity during secondary succession of a subtropical forest in China. Journal of Vegetation Science, 25: 897-9II, 2014.

BUTTERFIELD, B.J. AND SUDING, K.N. Single-trait functional indices outperform multi-trait indices in linking environmental gradients and ecosystem services in a complex landscape. Journal of Ecology, I0I: 9-17, 2013.

CASANOVES, F., PLA, L., DI RIENZO, J., DIAZ, S. 2011. FDiversity: a software package for the integrated analysis of functional diversity. Methods in Ecology and Evolution 2: 233-237, $201 \mathrm{I}$.

CUI, G.F., XING, S.H., ZHAO, B. Conservation of mountain plants and vegetation in Beijing. Beijing: China Forestry Press. (In Chinese), 2008.

DAI, X.B., CHEN L.Z., HUANG, J.H. The restoration of the destroyed forest vegetation in Yunmeng Mountain, Beijing. Vegetatio, 87: 145-150, 1990.

DE BELLO, F., LEPŠ, J. AND SEBASTIA, M.T. Variations in species and functional plant diversity along climatic and grazing gradients. Ecography 29: 80I-810, 2006.

DE BELLO, F., THUILLER, W., LEPŠ, J., CHOLER, P., CLEMENT, J., MACEK, P., SEBASTIA, M. T. AND LAVOREL, S. Partitioning of functional diversity reveals the scale and extent of trait convergence and divergence. Journal of Vegetation Science 20: 475-486, 2009.

DUIVENVOORDEN, J.F., CUELLO, N.L. Functional trait state diversity of Andean forests in Venezuela changes with altitude. Journal of Vegetation Science23: I I05-I I I3, 20 I2.

FETENE, M., ASSEFA, Y., GASHAW, M., WOLDU, Z. AND $B E C K$, E. Diversity of afroalpine vegetation and ecology of treeline species in the Bale Mountains, Ethiopia, and the influence of fire. In Spehn, E. M., Liberman, M. and Korner, C. ed. Land Use Change and Mountain Biodiversity, CRC PRESS, New York: 25-38, 2006. 
HE, S.Y, XING, Q.H., YIN, Z. T. Flora of Beijing. Beijing: Beijing Press. (In Chinese), 1992.

LOMOLINO, M.V. Elevation gradients of species diversity: historical and prospective views. Global Ecology and Biogeography 10: 3-13, 2001.

MASON, N. W. H., MOUILLOT, D., LEE, W. G. E WILSON, J. B. Functional richness, functional evenness and functional divergence: the primary components of functional diversity. Oikos II I(I): II2-I I8, 2005.

MUHUMUZA, M., BYARUGABA, D., Impact of land use on the ecology of uncultivated plant species in the Rwenzori mountain range, mid western Uganda. African Journal of Ecology, 47: 614-621, 2009.

PAVOINE, S., BONSALL, M.B. Measuring biodiversity to explain community assembly: a unified approach. Biological Review 86: 792-812, 201 I.

PERRONNE, R., MAUCHAMP, L., MOULY, A., GILLET, F. Contrasted taxonomic, phylogenetic and functional diversity patterns in semi-natural permanent grasslands along an altitudinal gradient. Plant Ecology and Evolution, 147: 165-175, 2014.

PETCHEY, O. AND GASTON, K. Functional diversity (FD), species richness and community composition. Ecology Letters 5(3): 402-4II, 2002.

PETCHEY, O. AND GASTON, K. Functional diversity: back to basics and looking forward. Ecology Letters 9(6): 74I-758, 2006.

PODANI, J. AND SCHMERA, D. On dendrogram-based measures of functional diversity. Oikos, II5, I79-185, 2006.

RICOTTA, C. AND MORETTI, M. Quantifying functional diversity with graph-theoretical measures: advantages and pitfalls. Community Ecology 9(I): II-16, 2008.

SONG, N.Q. ZHANG, J.T. An index for measuring functional diversity in plant communities based on neural network theory. Journal of Applied Mathematics, Volume 2013, Article ID 320905, 6 pages, 2013.
SPASOJEVIC, M. J., COPELAND, S., SUDING, K.N. Using functional diversity patterns to explore metacommunity dynamics: a framework for understanding local and regional influences on community structure. Ecography, 37: 939$949,2014$.

TARDELLA, F. M., PIERMARTERI, K., MALATESTA, L., CATORCI, A. Environmental gradients and grassland trait variation: Insight into the effects of climate change. Acta OecologicaInternational Journal of Ecology, 76: 47-60, 2016.

VILLEGER, S., MASON, N. W. H. AND MOUILLOT, D. New multidimensional functional diversity indices for a multifaceted framework in functional ecology. Ecology 89:2290-230I, 2008.

WANG, Z. J., CAI, J., ZHANG, Q.X. Effects of tourism on forest landscapes in Yunmengshan National Forest Park. Hebei Forestry Science and Technology, 20: 32-35. (in Chinese), 2004.

ZHANG, J.T., ZHANG, B., LI, M., ZHU, X. Functional diversity and conservation of Phellodendron amurense communities in the Dongling Mountain of Beijing, China. Botanical Sciences, 9I (4): 505-5I3, $2013 \mathrm{a}$.

ZHANG, J.T., XU, B., LI, M. Vegetation patterns and species diversity along elevational and disturbance gradients in the Baihua Mountain Reserve, Beijing, China. Mountain Research and Development, 33(2): I70-I78, 20।3b.

ZHANG, J.T., SONG, N.Q., FAN, L.H. Evaluation of nine distance-based measures of functional diversity applied to forest communities. Annals of Forest Research, 56(I): 4352. 20I3c.

ZHANG, J.T., LI, M. NIE, E.B. Pattern of functional diversity along an altitudinal gradient in the Baihua Mountain Reserve of Beijing, China. Brazilian Journal of Botany, 37: 37-45. 2014.

ZHANG, J.T., XIAO, J., LI, L.F. Variation of plant functional diversity along a disturbance gradient in mountain meadows of the Donglingshan Reserve, Beijing, China. Russian Journal of Ecology, 46(2): I57-166, 20I5a.

ZHANG, J.T., ZHANG, B., QIAN, Z.Y. 20I5b. Functional diversity of Cercidiphyllum japonicum communities in the Shennongjia Reserve, central China. Journal of Forestry Research, 26(I): I7I-177. 
